\title{
KAJIAN PENGGUNAAN METODE IP, STORET, dan CCME WQI DALAM MENENTUKAN STATUS KUALITAS AIR
}

\author{
Yuda Romdania 1 , Ahmad Herison², Gatot Eko Susilo³, Elza Novilyansa ${ }^{4}$ \\ 1, 2, 3Dosen Fakultas Teknik, Universitas Lampung, Bandar Lampung \\ 4Mahasiswa Fakultas Teknik, Universitas Lampung, Bandar Lampung \\ Gedong Meneng, Rajabasa, Kota Bandar Lampung, Lampung 35142 Indonesia
}

\begin{abstract}
ABSTRAK
Pemantauan kualitas air perlu dilakukan pada air sungai, laut, danau, rawa dan tanah sehingga dapat dimanfaatkan sesuai dengan kegunaannya bagi makhluk hidup. Kajian ini bertujuan untuk membandingkan beberapa metode perhitungan indeks kualitas air yang paling efektif, sensitif dan obyektif dalam menentukan status kualitas air permukaan. Metode perhitungan Indeks Kualitas Air (IKA) diperlukan untuk menyederhanakan banyaknya nilai dari berbagai jenis parameter menjadi sebuah angka tunggal yang mampu mendeskripsikan kualitas air, sehingga lebih mudah dipahami oleh masyarakat. Perhitungan IKA dengan menggunakan metode Storet, IP, dan CCME WQI (Canadian Council of Ministers of The Environment) dilaksanakan di beberapa penelitian di berbagai negara. Kajian ini akan membandingkan hasil literatur dari penelitian IKA di beberapa negara. Metode tersebut akan dibandingkan dengan beberapa indikator. Hasil kajian menunjukkan Metode IP lebih unggul jika memakai data tunggal karena memiliki kelebihan dari segi biaya dan waktu, namun hanya mempresentasikan status mutu air pada saat itu saja, tidak dalam periode tertentu. Metode Storet dan CCME menggunakan data perulangan sepanjang waktu (time series data) sehingga menggambarkan status mutu air dalam periode tertentu. CCME WQI lebih unggul dari Metode Storet dan Metode IP karena memperhitungkan besarnya selisih hasil pengujian yang melebihi baku mutu melalui $\mathrm{F}_{3}$ (Amplitude). Dari kajian di atas disimpulkan, Metode CCME merupakan metode yang paling tepat untuk menganalisis kualitas air baik pada air permukaan maupun air tanah dengan tingkat efektivitas dan sensitivitas yang lebih tinggi dibandingkan dengan metode lainnya serta penggunaan jumlah dan jenis parameter yang fleksibel.
\end{abstract}

Kata kunci : Kualitas Air, Indeks Kualitas Air, Air Permukaan

\section{PENDAHULUAN}

Air sumber daya alam utama dan aset nasional yang berharga. Selain untuk minum, sumber air memainkan peran penting di berbagai sektor ekonomi seperti pertanian, produksi ternak, kehutanan, kegiatan industri, pembangkit listrik, perikanan dan kegiatan kreatif lainnya. Namun, ketersediaan dan kualitas air baik permukaan atau tanah, telah memburuk karena beberapa faktor seperti meningkatnya populasi, industrialisasi, urbanisasi dan lain-lain (Tyagi et al., 2013). Kenaikan populasi dan industrialisasi menyebabkan permintaan air tawar meningkat dalam dekade terakhir. Permintaan ini khususnya dipenuhi oleh sungaisungai. Namun adanya limbah yang dibuang dari aktivitas manusia dan industri, kualitas air sungai memburuk.

Kualitas air merupakan tingkat kondisi cemar atau kondisi baik pada suatu sumber air dalam waktu tertentu dengan membandingkan kualitas air eksisting dengan baku mutu air yang ditetapkan (Kepmen LH No 115 Tahun 2003). Salah satu pendekatan untuk penentuan kualitas air sungai adalah Indeks Kualitas Air (IKA), yang terbukti menjadi metode yang efisien dan berguna untuk menilai kualitas air. Metode ini memberikan 
gambaran tentang kualitas keseluruhan air kepada pembuat kebijakan yang berkepentingan (Asadi et al., 2007).

Indeks kualitas air adalah mekanisme matematis untuk menghitung data kualitas air menjadi istilah sederhana misalnya Excelent, good, dan bad. Indeks Kualitas Air (Water Quality Index / WQI) adalah metode sederhana yang digunakan sebagai bagian dari survei kualitas air secara umum dengan menggunakan sekelompok parameter yang mengurangi sejumlah besar informasi ke nomor tunggal, biasanya berdimensi, dengan cara yang mudah direproduksi (Abbasi dan Abbasi, 2012). Kelas kualitas air didefinisikan tergantung parameter fisik, biologi dan kimia yang diukur selain untuk keperluan air yang digunakan seperti; air minum, air yang digunakan di pertanian, atau air yang digunakan di industri (Sargaonkar dan Deshpande, 2003).

Metode perhitungan indeks kualitas air sangat diperlukan untuk menyederhanakan banyaknya nilai dari berbagai jenis parameter menjadi sebuah angka yang mampu mendeskripsikan kualitas air sehingga mudah dipahami oleh masyarakat. Metode IKA yang sering digunakan di Indonesia yaitu Metode IP (Indeks Pencemaran) dan Metode Storet yang mengacu pada Keputusan Menteri Lingkungan Hidup No. 115 tahun 2003 tentang Pedoman Penentuan Status Mutu Air (Saraswati et al., 2014). Metode IP dan Storet lebih banyak dikembangkan di United State America (USA).

Selain kedua metode tersebut, terdapat pula metode OIP/Overall Index Pollution India yang dikembangkan di India, metode INWQS-DOE yang digunakan di Malaysia, dan metode CCME WQI (Canadian Council of Ministers of The Environment) yang dikembangkan di Canada (Lumb et al,. 2011).

Kajian ini bertujuan untuk menganalisa keunggulan penggunaan metode perhitungan indeks kualitas air dalam menentukan status kualitas air permukaan antara metode IP, Storet dan CCME WQI sehingga dapat diketahui metode yang paling efektif, sensistif dan obyektif.

\section{METODE}

Metode yang digunakan adalah membandingkan hasil perhitungan IKA dengan metode IP, Storet dan CCME WQI dari sembilan laporan penelitian kualitas air di Indonesia dan luar Indonesia, seperti India, Filipina, Cina, Iraq dan lainnya. Adapun penjelasan untuk masing-masing metode Indeks Kualitas Air adalah sebagai berikut:

\section{a. Metode Indeks Pencemaran (Desmawati, 2014)}

Metode IP dibangun berdasarkan dua indeks kualitas. Yang pertama adalah indeks rata-rata (IR). Indeks ini menunjukkan tingkat pencemaran rata-rata dari seluruh parameter dalam satu kali pengamatan. Yang kedua adalah indeks maksimum (IM). Indeks ini menunjukkan satu jenis parameter yang dominan menyebabkan penurunan kualitas air pada satu kali pengamatan (Marganingrum, 2013). Untuk Status mutu air dari hasil perhitungan Indeks Pencemaran dikonversi sesuai dengan indeks status mutu air berdasarkan Kepmen LH No. 115 Tahun 2003.

\section{b. Metode Storet (Khairil, 2014)}

Penentuan status mutu berdasarkan metode Storet dilakukan dengan cara membandingkan data kualitas air dengan baku mutu yang telah ditetapkan sesuai dengan peruntukannya. Metode ini dapat diketahui parameter-parameter yang telah memenuhi atau melampaui baku mutu air. Cara menentukan status mutu air digunakan sistem nilai dari US-EPA (Environmental Protection Agency), sementara langkah-langkah 
penentuan status mutu air dengan disesuaikan dengan petunjuk pada Lampiran I Kepmen LH No. 115 Tahun 2003.

\section{c. Metode CCME (Lumb et al., 2011)}

CCME WQI merupakan suatu alat yang disederhanakan bagi masyarakat umum untuk memperoleh data kualitas air yang kompleks. Indeks kualitas air ini diformulasikan oleh British Columbia Ministry of Environment, Lands and Parks yang kemudian dikembangkan oleh Alberta Environment. (CCME, 2001).

Jenis parameter, baku mutu dan jangka waktu yang digunakan pada indek ini sangat bervariasi tergantung pada isu-isu dan kondisi lokal setiap wilayah. Penentuannya digunakan pada indek ini tidak ditentukan dan sangat bervariasi dari antar daerah Itergantung pada isu-isu dan kondisi lokal pada masing-masing daerah. Minimal terdapat empat contoh variabel untuk empat kali digunakan dalam perhitungan indeks ini. Metode ini berguna dalam mengevaluasi perubahan kualitas air pada lokasi tertentu dari waktu ke waktu dan untuk membandingkan indeks secara keseluruhan antar lokasi yang menggunakan variabel dan baku mutu yang sama.

CCME WQI dapat dihitung dengan menggunakan rumus sebagai berikut :

1. F1 (Scope),

2. F2 (Frequency),

a) F3 (Amplitude), Jumlah waktu dimana konsentrasi masing-masing lebih besar atau kurang dari baku mutu minimum baku mutu. Ini disebut "excursion".

Jika nilai uji lebih dari baku mutu:

b) Uji excursion dari baku mutu dan membagi total nilai uji (baik yang terpenuhi dan yang tidak terpenuhi).

Variabel ini disebut sebagai jumlah normalisasi excursion atau nse dihitung sebagai berikut:

c) F3 kemudian dihitung dengan fungsi asimtotik dengan skala jumlah dari nse dengan kisaran harga antara 0 hingga 100.

Indeks CWQI menghasilkan angka antara 0 (terjelek) hingga 100 (terbaik) yang terbagi dalam 5 kelas yaitu baik sekali (95-100), baik (80-94), cukup (65-79), kurang (45-64), dan buruk (0-44) dalam merefleksikan status mutu/kualitas air (Lumb et al., 2011)

\section{HASIL DAN DISKUSI}

Berikut beberapa penelitian mengenai penentuan status kualitas air (IKA) dengan metode Storet, IP, dan CCME yang dapat dijadikan referensi pada penelitian selanjutnya. Pertama, penelitian yang dilakukan Saraswati dilakukan di Sungai Gadjah Wong DI Yogyakarta tahun 2014. Penelitian ini membahas tentang sensitivitas rumus indeks PI, Storet, dan CCME untuk penentuan status mutu perairan sungai tropis di Indonesia.

Lokasi penelitian di 8 lokasi titik pantau yang berada di sungai utama. Parameter yang digunakan dalam analisis sebanyak 17 parameter yaitu : pH, EC, TDS, TSS, DO, BOD5, COD, Deterjent, PO4, NO2, NO3, $\mathrm{NH} 3 \mathrm{~N}$, Escherichia coli/E. Coli, Total Coliform/Total Coli, Cr6+, Fluoride/F, Minyak dan Lemak). Berdasarkan 17 parameter kualitas air (termasuk bakteriologi) status indeks mutu air PI, CCME tercemar berat (poor atau heavily polluted) di hampir semua lokasi pemantauan, bahkan menurut Storet semua lokasi tercemar berat. Jika masing-masing metode indeks mutu air dihitung dengan 6 parameter kualitas air dalam OIP yaitu $\mathrm{pH}, \mathrm{TDS}, \mathrm{BOD}_{5}, \mathrm{DO}, \mathrm{NO}_{3}$ dan $\mathrm{F}$, tetapi plus bakteriologi (dimana $\mathrm{DO}, \mathrm{BOD}_{5}, \mathrm{~F}$, Total Coli tidak memenuhi baku mutu) juga menunjukkan status mutu air tercemar be rat hampir di semua lokasi 
dan di sebagian besar datanya. Parameter kualitas air yang menjadi penyebab signifikan buruknya status mutu air dengan ketiga metode tersebut adalah bakteriologi ( $E$. coli dan Total Coli) yang besaran nilai kosentrasinya sangat signifikan yaitu ratusan ribu hingga jutaan bakteri MPN/100 ml airnya (Saraswati et al., 2014).

Indeks PI dengan sedikit atau banyak parameter kualitas air (3, 4 atau 9 parameter tidak memenuhi baku mutu) tidak cukup sensitif membedakan kelas status mutu air di setiap lokasi sampel dan saat sampling kualitas airnya. Nilai rasio (Ci/Lij) maksimum masing-masing parameter tersebut berkisar antara 0,4 hingga 6,2 sementara rerata $(\mathrm{Ci} / \mathrm{L} i j)$ seluruh parameternya ( 3 hingga 9 parameter tidak memenuhi baku mutu) berkisar 0,4 hingga 3 . Status mutu air dengan indeks $\mathrm{PI}$, hanya dari satu ( single) sampling kualitas air.

Indeks Storet cukup sensitif merespon dinamika indeks kualitas airnya di setiap lokasi dengan sedikit atau banyak parameter. Akan tetapi status indeksnya sangat dipengengaruhi oleh bobot parameter biologi (bakteriologi) dibandingkan kimia dan fisika. Hal positifnya adalah indeks mutu air ini tidak mencerminkan data kualitas air instan (efek jangka pendek), status mutu air dihitung/disimpulkan dari serangkaian data hasil beberapa kali pengambilan spesimen kualitas air (efek jangka panjang).

Hasil penelitiannya menunjukkan bahwa metode IP, Storet, dan CCME sama-sama mempunyai fleksibilitas jumlah dan jenis parameter kualitas air untuk menentukan status mutu air. Namun fleksibilitas ini akan membuat ketidakseragaman dalam penggunaan parameter kualitas air yang penting untuk penentuan indeks kualitas air di suatu sungai. Metode CCME paling sensitif merespon dinamika mutu air di setiap lokasi pemantauan dengan sedikit dan banyak parameter, dengan dan tanpa parameter bakteriologi. Kajian beberapa metode IKA ini memperlihatkan parameter kualitas air E. coli dan Total Coliform sangat dominan mempengaruhi status indeks mutu air sungai (Saraswati et al., 2014).

Kedua, penelitian yang dilakukan oleh Yusrizal pada tahun 2015 di Sungai Way Sekampung, Provinsi Lampung. Penelitian tersebut menganlisis efektifitas antara metode Storet, IP, dan CCME WQI dalam menentukan status kualitas air di Way Sekampung Provinsi Lampung. Penelitian ini menggunakan data hasil uji parameter air dari BPLHD Propinsi Lampung Tahun 2013 dan 2014, Parameter yang digunakan sebanyak 23 parameter yaitu : pH, Suhu, DHL, DO, Kekeruhan, TDS, Salinitas, BOD, COD, Amonia, Nitrat, Nitrit, Sulfat, Sulfida, total fosfat, Sianida, Chlorida, MBAS/detergen, Fluorida, Minyak Lemak, Tembaga, Seng dan TSS. Dari perhitungan dengan menggunakan ketiga metode tersebut, yaitu Storet, IP dan CCME WQI, semuanya mempunyai kesamaan yaitu kecenderungan nilai status mutu air yang semakin membaik dari pengambilan sampel yang pertama hingga yang ketiga.

Dari ketiga hasil perhitungan tersebut, tampak bahwa metode Storet menggambarkan hasil yang lebih "cemar" dibandingkan dengan metode lain. Perhitungan dengan metode CCME WQI lebih logis karena memperhitungkan besaran selisih hasil pengujian dibandingkan dengan baku mutunya. Hal ini tidak tampak pada metode Storet. Metode CCME WQI seperti juga Storet menggunakan data perulangan sepanjang waktu (time series data) tidak seperti IP yang menggunakan data tunggal, sehingga status mutu air yang dihitung dengan menggunakan metode CCME WQI lebih menggambarkan status mutu air pada periode tertentu, tidak sesaat seperti pada metode IP. 
Tabel 3. Perbandingan Status Mutu Air dengan metode Storet, IP dan CCME WQI

\begin{tabular}{|c|c|c|c|c|c|c|c|}
\hline \multirow[t]{2}{*}{ NO. } & \multirow{2}{*}{$\begin{array}{c}\text { KOORDINAT GPS/ } \\
\text { TITIK } \\
\text { PENGAMBILAN } \\
\text { SAMPEL }\end{array}$} & \multicolumn{2}{|c|}{ STORET } & \multicolumn{2}{|c|}{$\begin{array}{c}\text { Indeks } \\
\text { Pencemaran }\end{array}$} & \multicolumn{2}{|c|}{ CCME WQI } \\
\hline & & Nilai & SMA & $\begin{array}{l}\text { Cemar } \\
\text { sedang }\end{array}$ & $\begin{array}{l}\text { Cemar } \\
\text { ringan }\end{array}$ & Nilai & SMA \\
\hline 1. & $\begin{array}{c}\text { 104058'65,1" BT } \\
05^{\circ} 19^{\prime} 60,3^{\prime \prime} \text { LS }\end{array}$ & -45 & $\begin{array}{l}\text { Cemar } \\
\text { Berat }\end{array}$ & 2 & 5 & 62,607 & Marginal/rendah \\
\hline 2. & $\begin{array}{c}105^{\circ 1} 0^{\prime} 75,6^{\prime \prime} \text { BT } \\
05^{\circ} 11^{\prime} 94,2 \text { " LS }\end{array}$ & -39 & $\begin{array}{l}\text { Cemar } \\
\text { Berat }\end{array}$ & 1 & 6 & 64,263 & Marginal/rendah \\
\hline 3. & $\begin{array}{c}105^{\circ} 47^{\prime} 32,6^{\prime \prime} \text { BT } \\
05^{\circ} 36^{\prime} 69,6^{\prime \prime} \text { LS }\end{array}$ & -38 & $\begin{array}{l}\text { Cemar } \\
\text { Berat }\end{array}$ & 1 & 6 & 68,864 & Fair/cukup \\
\hline
\end{tabular}

Catatan : SMA = Status Mutu Air

Sumber $=$ Yusrizal, 2015

Status Mutu/Kualitas Air Way Sekampung tahun 2013 dan 2014 berdasarkan metode Storet dari 3 titik pengambilan sampel adalah tercemar berat. Berdasarkan metode Indeks Pencemaran (IP), dari 21 kali pengukuran, pada titik pengambilan sampel pertama (SK-01) 2 kali cemar sedang dan 5 kali cemar ringan. SK-02, 1 kali cemar sedang dan 6 kali cemar ringan. SK-03, 1 kali cemar sedang dan 6 kali cemar ringan. Berdasarkan metode CCME WQI, status mutu air di titik pengambilan sampel pertama (SK- 01) dan SK-02 adalah Marginal/rendah, sedangkan SK-03 adalah Fair/cukup. Lihat Tabel 2.

Hasil penelitian menunjukkan ke 3 metode ini mempunyai kelebihan dan kekurangan masing-masing. Metode Storet dan CCME WQI unggul di dalam penggunaan serangkaian data yang berulang dari hasil beberapa kali pengambilan sampel, sehingga status mutu airnya lebih menggambarkan kondisi kualitas air pada periode tertentu. Dari segi efektivitas metode dilihat berdasarkan uji sensitivitas parameter, maka metode CCME WQI lebih baik dibandingkan dengan metode Storet dan metode IP karena metode CCME WQI telah memperhitungkan besarnya selisih hasil pengujian yang melebihi baku mutu, dengan baku dengan baku mutunya, melalui F3 (Yusrizal, 2015).

Ketiga, penelitian kualitas air laut di Teluk Lampung oleh Verawati (2013). Kualitas air laut dihitung menggunakan metode CCME WQI, Storet dan IP berdasarkan wilayah dan tahun pengukuran pantau di 6 lokasi dengan 7 parameter air laut yaitu : pH, Suhu, Salts, DO, Amonia, Nitrat, Fosfat. Dari tabel 4, indeks CCME mengindikasikan perairan dengan tingkat pencemaran yang lebih tinggi dibandingkan indeks Storet dan PI. Misalnya untuk hasil evaluasi indeks di perairan Teluk Hurun, indeks CCME mengindikasikan wilayah Teluk Hurun dengan kategori buruk (poor). PI mengindikasikan perairan dalam kategori cemar sedang. Sementara indeks Storet mengindikasikan perairan dalam kategori baik (cemar ringan). Hasil analisis dari ketiga metode tersebut menunjukkan bahwa indeks kualitas air yang dihasilkan dari metode CCME WQI mengindikasikan perairan dengan tingkat pencemaran yang lebih tinggi dibandingkan indeks kualitas air dengan metode Storet dan IP (Verawati, 2016).

Keempat, penelitian indeks kualitas air di Sungai Damodar, wilayah Bengal Selatan, India. Pemantauan kualitas air dilakukan dengan metode CCME WQI. Pengambilan sampel air di 8 titik di sepanjang tepi sungai pada saat sebelum musim hujan, musim hujan, dan pasca musim hujan periode tahun 2012. Jumlah parameter yang diuji sebangk 16 buah yaitu : pH, TDS, TSS, conductivity ( $\mu$ s), kekeruhan, DO, BOD, COD, Kesadahan, Kalsium, magnesium, alkalinity, minyak, lemak, Coliform, chromium, chlorida florida, calcium magnesium, sulfat phosphate, dan nitrat. Berdasarkan analisis CCME WQI air di sungai Damodar layak 
digunakan untuk keperluan rumah tangga dan irigasi, namun harus dilakukan pengolahan terlebih dahulu jika akan digunakan sebagai air minum. Kondisi iklim sangat mempengaruhi kualitas air sungai. Hal ini karena kualitas air setelah musim hujan lebih baik dibanding sebelum dan pada saat musim hujan. Lokasi terakhir (D8) Sungai Damodar mempunyai kualitas air sangat tercemar karena pembuangan limbah domestik, pembuangan limbah industri, sampah, dan pencemaran karena aktivitas manusia lainnya. Diperlukan tindakan pencegahan dan tindakan pengaturan dengan melakukan pemantauan untuk mencegah polutan yang melebihi ambang batas yang diizinkan (Haldar, et al, 2014)

Kelima, penelitian dilakukan di Sungai Mahrut, Diyala, Iraq. Pemantauan kualitas air dilakukan untuk kebutuhan irigasi dengan metode CCME WQI dengan 15 parameter yaitu : pH, EC, $\mathrm{HCO} 3, \mathrm{Cl}$, Sodium Absorption Ratio (SAR), Soluble Sodium Percentage (SSP), Residual Sodium Carbonate (RSC), Cd, $\mathrm{Cr}, \mathrm{Cu}, \mathrm{Fe}, \mathrm{Pb}, \mathrm{Mn}, \mathrm{Ni}$ dan $\mathrm{Zn}$. Menggunakan data dengan dua musim yang berbeda yaitu periode tahun 2010-2011. Dari hasil analisis kualitas air di Sungai Mahrut, nilai CCME WQI berada pada rentang nilai antara 43,17 - 45,11. Kualitas air pada titik pantau 1 masuk kategori kurang baik sedangkan pada 5 stasiun lainnya dalam kondisi buruk sehingga dapat disimpulkan bahwa kondisi air pada sungai mahrut dalam kondisi buruk. Kemungkinan penyebab buruk nya kualitas air tersebut disebabkan karena limbah domestik, limbah industri, limbah pupuk pertanian dan sumber pencemaran lain yang masuk ke sungai tanpa melalui pengolahan limbah terlebih dahulu (Alobaidy et al., 2015).

Keenam, pemantauan kualitas air di Sungai Seybouse (timur laut Algeria) dengan metode CCME WQI menggunakan data di 13 lokasi berdasarkan parameter fisika, kimia dan biologi. Sampel air dari tengah dan dua tepi Sungai Seybouse. selama bulan Mei 2012 sampai April 2013. Jumlah parameter yang digunakan sebanyak 11 parameter yaitu : pH , Suhu, DO, Nitrit, Nitrat, Nitrogen Chlorida, Tembaga Cadmium, Aluminum, Turbidity. CCME WQI merupakan alat yang efektif untuk mengevaluasi kualitas air untuk keperluan air minum. Model WQI yang digunakan untuk menilai kualitas air minum di Sungai Seybouse menunjukkan bahwa kualitas air 'buruk', dengan nilai indeks berkisar antara 18,3 sampai 30,4. Air limbah yang dibuang langsung atau tidak langsung ke badan air merupakan sumber utama polutan. WQI telah mengumpulkan data kualitas air yang kompleks sehingga mudah dipahami dan informasi ini bisa sangat bermanfaat bagi pengguna air, pemasok air dan ilmuwan (Rachedi dan Amarchi, 2015).

Ketujuh, pemantauan kualitas air pada Sistem Sungai Pasig di Metro Manila. Pengujian status pencemaran dengan metode perhitungan WQI CCME untuk ekosistem perairan dan rekreasi. Penelitian ini dilakukan di 14 titik sepanjang Sungai Pasig di Metro Manila, dengan 4 parameter : pH, DO, BOD, TC. Menggunakan data uji laboratorium setiap tiga bulan dari kuartal pertama tahun 2011 sampai kuartal kedua tahun 2014. Hasil Analisis CCME WQI menunjukkan bahwa perairan di sungai Pasig masuk dalam kategori buruk, baik untuk ekosistem perairan maupun untuk rekreasi. Sistem pembuangan limbah yang tidak memadai dan air limbah yang tidak diolah dari sumber domestik, pertanian, komersial dan industri merupakan faktor utama yang menyebabkan kontaminasi sistem Sungai Pasig (Regmi dan Mishra, 2015).

Kedelapan, pemantauan kualitas air di Waduk Three Gorges, Cina. Penelitian dilaksanakan di 24 lokasi pemantauan air. Jumlah parameter yang digunakan sebanyak 12 Parameter yaitu : pH, DO, COD, Mn, BOD5, TP, volatile phenol, NH3-N, mercury, lead, COD, TN, and E. coli. . Periode pengambilan sampel tahun 2012013. Metode yang digunakan adalah metode CCME WQI dengan standar kualitas air kelas 3 menurut GB3838-2002. Hasil penelitian ini menunjukkan bahwa 3 parameter utama yang menyebabkan penurunana kualitas air di TGR yaitu TN, TP dan E-Coli. kualitas air tidak mengalami penurunan yang signifikan pada kondisi ketinggian air di TGR $175 \mathrm{~m}$. Di beberapa stasiun pantau yang berada di sungai kecil, kualitas air nya tidak sebaik kualitas air disungai utama. Metode CCME WQI merupakan metode yang fleksibel untuk mengevaluasi kualitas air. Dikombinasikan dengan GB3838-2002, CCME WQI dapat menyederhanakan 
jumlah data pemantauan kualitas air yang kompleks sehingga mudah dipahami oleh pembuat kebijakan dan masyarakat (Zhao et al., 2016).

Kesembilan, Uji kualitas air sungai dilakukan pada DAS Ogun dan Ona, Nigeria. Pengambilan sampel di 27 lokasi pemantauan air yang berada di 8 sungai utama pada DAS Ogun dan Ona . Jumlah parameter yang digunakan sebanyak 12 Parameter yaitu : Suhu, EC, pH, DO, BOD5, COD, Total keasaman, kekeruhan, TSS, ammonium-nitrogen, nitrate-nitrogen, nitrite-nitrogen,TN, TP, phosphateC, Besi, cadmium, zinc, mercury, copper, Mangan, lead, chromium, Total Viable Bacteria Count (TVC), Escherichia coliform (E. coli) and faecal coliform. Periode pengambilan sampel selama 12 bulan. Metode yang digunakan adalah metode CCME WQI dengan standar kualitas air untuk kebutuhan rumah tangga menurut WHO. Hasil penelitian ini menunjukkan bahwa kualitas air di DAS ini buruk sehingga tidak direkomendasikan untuk kebutuhan rumah tangga (Oke et al., 2017).

\section{KESIMPULAN}

Dari kajian di atas dapat disimpulkan bahwa Metode CCME merupakan metode yang paling tepat untuk menganalisis kualitas air di berbagai negara termasuk Indonesia baik pada air permukaan maupun air tanah dengan tingkat efektivitas dan sensitivitas lebih tinggi dibandingkan dengan metode lainnya serta penggunaan jumlah dan jenis parameter yang fleksibel. CCME WQI menggunakan data perulangan sepanjang waktu (time series data) sehingga menggambarkan kondisi lingkungan yang sebenarnya dalam periode tertentu. Sementara kekurangan dari metode CCME WQI adalah metode perhitungannya lebih kompleks bila dibandingkan dengan metode storet dan metode IP yang perhitungannya lebih sederhana.

\section{REFRENSI}

Abbasi, T., Abbasi, S.A., 2012. Water quality indices. Elsevier, Amsterdam, Netherlad, pp. 384.

Alobaidy, A.H.M.J., Abid, H.S., Maulood, B.K., 2010. Application of water quality index for Dokan Lake Ecosystem, Iraq. J. Water Res. Prot. 2, 792-798.

Alobaidy A.H.M.J., Al-Janabi, Z.Z., Al-Kubaisi, A.R. 2015. Assessment of water quality of Tigris River within Baghdad City. Mesopotamia Environmental Journal. Vol.1, No.3:pp. -98.

Alobaidy, A.H.M.J., Awad, E.S., Kadhem, A.J., AlMashhady, A.A. 2015. Evaluating Water Quality of Mahrut River, Diyala, Iraq for Irrigation. , 33(4), pp.830-837.

Asadi, S.S., Vuppala, P., Anji, R.M., 2007. Remote sensing and GIS techniques for evaluation of groundwater quality in municipal corporation of Hyderabad (Zone-V), India. Int. J. Environ. Res. Public Health 4 (1), 45-52.

Canadian Council of Ministers of the Environment (CCME). 2001. Canadian water quality guidelines for the protection of Aquatic life: CCME Water Quality Index 1.0. Technical Report. Canadian Council of Ministers of the Environment, Winnipeg, MB, Canada.

Desmawati, Eka. 2014. Sistem Informasi Kualitas Air Sungai di Wilayah Sungai Seputih Sekampung. Tesis Magister Teknik Universitas Lampung. Bandar Lampung. 
Haldar, D., Halder, S., Das, P., Halder, G. 2014. Assessment of water quality of Damodar River in South Bengal region of India by Canadian Council of Ministers of Environment (CCME) Water Quality Index: a case study. Desalination and Water Treatment. (February 2015), pp.1-14. Available at: http://www.tandfonline.com/doi/abs/10.1080/19443994. 2014. 987168.

Khairil, A.S., Moh, S., Emma, Y. 2014. Kajian penentuan status mutu air di Kali Kloang Kabupaten Pameksan (Metode Storet, Metode Indeks Pencemaran, Metode CCME WQI, dan Metode OWQI). Teknik Pengairan Universitas Brawijaya-Malang. Jawatimur. Indonesia.

Lumb, A., Sharma, T.C., Bibeault, J.F., 2011. A Review of genesis and evolution of water quality index (WQI) directions. Water Qual. Expo. Health 3,11-24.

Marganingrum, D., Roosmin, D., Sabar, A., 2013. Diferesiasi Sumber Pencemar Sungai Menggunakan Pendekatan Metode Indeks Pencemar (IP) (Studi Kasus : Hulu DAS Citarum). Pusat Penelitian Geoteknolog Lembaga Ilmu Pengetahuan Indonesia. Ris.Geo.Tam Vol. 23, No.1, Juni 2013 (37-48).

Oke, A.O., Sangodoyin, A.Y. \& Omodele, T., 2017. Classification of river water quality in Ogun and Ona River Basins , Nigeria using CCME framework: Implications for sustainable environmental management Classification of river water quality in Ogun and Ona. Cogent Environmental Science, 6, pp.1-18. Available at: http://dx.doi.org/10.1080/23311843.2017. 1295696.

Rachedi, L.H. \& Amarchi, H., 2015. Assessment of the water quality of the Seybouse River ( north-east Algeria ) using the CCME WQI model Lamia Hachemi Rachedi and Hocine Amarchi. , pp.793-801.

Ramakrishnaiah, C.R., Sadashivaiah, C., Ranganna, G., 2009. Assessment of water quality Index for the groundwater in Tumkur Taluk, Karnataka State, India. Electron. J. Chem. 6 (2), 523-530.

Regmi, R.K. \& Mishra, B.K., 2016. Use of Water Quality Index in Water Quality Assessment : A Case Study in the Metro Manila. , (07).

Republik Indonesia. 2003. KepMen LH No. 115 Tahun 2003 tentang Pedoman Penentuan Status Mutu Air. Jakarta: Sekretariat Negara

Saraswati, S.P., Sunyoto, S., Kironotom, B.A., Hadisusanto, S. 2014. Kajian Bentuk dan Sensitivitas Rumus Indeks PI, Storet, CCME untuk Penentuan Status Mutu Perairan Sungai Tropis Indonesia. Manusia dan Lingkungan, 21(2), pp.129-142.

Sargaonkar, A., Deshpande, V., 2003. Development of an overall index of pollution for surface water based on a general classifica- tion scheme in Indian context. Environ. Monit. Assess. 89, 43-67.

Tyagi, S., Sharma, B., Singh, P., Dobhal, R. 2013. Water quality assessment in terms of water quality index. American Journal of Water resources 1.3 (2013) : 34-38.

Verawati. 2016. Analisis Kualitas Air Laut Di Teluk Lampung. Tesis Magister Teknik Universitas Lampung. Bandar Lampung.

Yusrizal, H., 2015. Efektivitas metode perhitungan Storet, IP dan CCME WQI dalam menentukan status kualitas air way sekampung provinsi lampung. 2(1), pp.11-23. 
Zhao, Y., Qin, Y., Zhang, L., Zheng, B., May, Y. 2016. Water quality analysis for the Three Gorges Reservoir, China , from 2010 to 2013. Environmental Earth Sciences. Available at:"http://dx.doi.org/10.1007/s12665-016-59541. 